doi: $10.15330 / m s u c .2019 .20 .11-15$

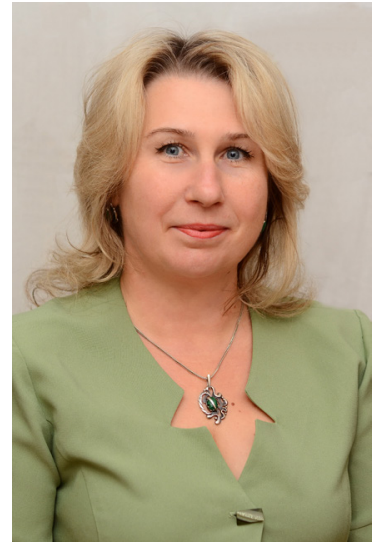

Галина Русин,

кандидат педагогічних наук, доцент кафедри

педагогіки початкової освіти,

ДВНЗ «Прикарпатський національний університет

імені Василя Стефаника»

(м. Івано-Франківськ, Україна)

\author{
Halyna Rusyn, \\ $\mathrm{PhD}$ in Education, Associate Professor, \\ Department of Pedagogy of Primary Education, \\ Vasyl Stefanyc Precarpathian National University \\ (Ivano-Frankivsk, Ukraine) \\ grusyn@gmail.com \\ ORCID ID 0000-0001-9601-5466
}

УДК 371.1:37.036

\title{
ОСВІТА ЯК ЦІННІСНА ДОМІНАНТА У ВИХОВАННІ МОЛОДІ
}

Анотація. У статті акцентується увага на окремих аспектах формування духовно-культурних цінностей молоді в закладах вищої освіти. Розкрито основні поняття «цінності», «ціннісні орієнтації», «духовно-культурні цінності освіти». Доведено, що саме освіта у вищих навчальних закладах повинна систематизувати та поглибити життєвий досвід молодої людини, оскільки є частиною духовної культури особистості та здійснює вплив на формування моральних цінностей, сприяє подальшому розвитку духовного світу, здібностей і творчого потенціалу.

Автор робить висновок, що становлення духовного світу молоді має вирішальне значення не лише для життя теперішнього покоління, але й усього суспільства загалом, тому особливу увагу слід приділити саме формуванню духовно-культурних цінностей освіти як основи для розвитку всебічно та гармонійно розвиненої особистості.

Таким чином, духовно-культурні цінності освіти дають можливість усвідомити значущість освіти як об'єкта і суб'єкта цивілізаційних змін та трансформацій; сформувати в молоді розуміння необхідності отримання нею «випереджувальної» освіти на засадах духовно-культурних цінностей в умовах зростаючого взаємопроникнення культур і загальнолюдських цінностей.

Ключові слова: цінності, ціннісні орієнтації, духовно-культурні цінності освіти, заклади вищої освіти.

\section{EDUCATION AS A VALUE DOMINANT IN THE EDUCATION OF YOUTH}

Abstract. The article reveals the basic concepts of «value», «value orientation», «spiritual and cultural value of education». Education in higher education institutions should systematize and deepen the life experience of young people. That is a certain basis of the spiritual world of personality. They reflect the attitude of man to the world, to himself and influence the activity of man in society, bringing meaningto his life. Due to value orientations, young people are mastered by the achievements of the spiritual culture of society. The content of education is enriched through the accumulation of knowledge about the world, which is assimilated by man in the process of forming certain value orientations in her. This knowledge contributes to a better understanding of values and traditions of other cultures by people and promotes the formation of a new system of positive values among students.

Education becomes the main tool for forming the harmonious inner world of the student's personality, contributes to the further development of his abilities to quickly find a way out of a variety of conflict situations, both personal (internal spiritual, moral) and social content. It greatly enhances the ability of a person to actualize the personally necessary parameters for life in the modern world such as spiritual integrity, activity and autonomy, gradually combining them into a certain system of agents that have a positive effect on the procesd of self-realization of the individual in the realities of the modern world which is constantly changing. Therely significantly minimizing the probability of occurrence of a feeling of insecurity of the individual, which arises after receiving a large amount of negative information.

Education is the part of the spiritual culture of the individual and influences the formation of the moral record of a person, promotes the further development of his spiritual world, abilities and creative potential of the individual. It is extremely important to draw attention to the need to form the spiritual and cultural values of education of modern students, which will become the basis for the translation of the development of a harmoniously and comprehensively developed, broad-minded, spiritually and culturally educated personality.

Keywords: value, value orientations, spiritual and cultural values of education, institutions of higher education

\section{ВСТУП}

Постановка проблеми. Освіта завжди відігравала важливу роль у формуванні гармонійної, успішної, молодої людини. Незважаючи на реалії тої чи іншої епохи, вона залишалася незмінною рушійною силою духовно-культурного розвитку особистості. Перед освітою постав ряд викликів і проблем, які перешкоджають iї розвитку. Надмірне домінування матеріальних цінностей над духовними, заміна істинних цінностей 
антицінностями, подальша дегуманізація освіти, відчуження знань і маркетизація освіти стали причинами майже повного знецінення знань. Втрата духовно-культурного потенціалу освіти, що негативно позначилася на сучасній молоді, призвела до втрати своєї індивідуальності, зосередження на досягненні матеріального благополуччя. Недостатня увага наділяється духовно-культурному розвитку.

Тому сьогодні гостро відчувається необхідність у переакцентуванні вищої освіти на духовно-культурний розвиток особистості студента, формування в нього духовно-культурних цінностей освіти як основ для трансляції духовної, а не матеріальної культури, розвитку не просто грамотної людини, а й обізнаної, широкомислячої.

Аналіз останніх досліджень і публікацій. Чимало сучасних учених вивчають питання сутності освіти, її цінностей загалом та духовно-культурних зокрема. Так, філософські основи окресленої проблеми розкрито у працях Н. Багдасарьян, 3. Залевської, С. Клепко, А. Суббето, Н. Селезньової, В. Огнев'юка, М. Покровського, А. Ярошенко та інших. Педагогічний аспект духовності, духовної культури, духовно-культурних цінностей освіти розглядали В. Андрущенко, Т. Антоненко, І. Бех, А. Кір'якова, В. Краєвський, Т. Кривко, Г. Назарова, С. Нєкрасова, О. Нікіфорова, С. Ніколаєнко, М. Міхалкович, С. Плаксій, О. Поздняков, М. Роганова, В. Садовнічев, Г. Шевченко та інші.

META I ЗАВДАННЯ ДОСЛІДЖЕННЯ: розкрити та проаналізувати сутність духовно-культурних цінностей освіти, їх вплив на формування сучасної студентської молоді у ВНЗ.

МЕТОДИ ДОсЛІДЖЕННЯ: вивчення та аналіз філософської і психолого-педагогічної літератури для розкриття сутності теоретико-методологічних підходів до проблеми дослідження; теоретичне узагальнення і систематизація, за допомогою яких була дана характеристика проблемного поля дослідження і з'ясована сутність духовно-культурних цінностей освіти.

\section{РЕЗУЛЬТАТИ ДОСЛІДЖЕННЯ}

Філософи нового часу звернули увагу на суб'єктивність, відносність цінностей, підкреслюючи, що те, яке цінне і значуще для однієї людини, не має жодної вартості для іншої, і тому цінності не можуть бути істинними в науковому плані. Г. Ріккерт, аналізуючи сутність поняття «цінність», зауважував, що вона «полягає в їх значущості, а не фактичності». Таким чином, цінності розглядаються як ідеальна загальна норма, яка надає реальності змісту (Антоненко Т. Л., 2008, с. 92).

У вітчизняній філософській думці проблема цінностей стала предметом ґрунтовного аналізу у другій половині XX століття. Як зазначає В. Тугарінов, значущість цінностей опосередкована орієнтацією людини на інших людей, на суспільство в цілому, на існуючі в ньому ідеали, уявлення і норми. Учений наголошує на тому, що окрема особа може користуватися лише цінностями, які наявні в певному суспільстві, і доходить висновку, що цінності життя окремої людини є за своєю суттю цінностями суспільного життя (Якісна освіта, 2007).

У філософському словнику термін «цінності» подається як «специфічно соціальне визначення об'єктів навколишнього світу, які виявляють їх позитивне та негативне значення для людини та суспільства (благо, добро, зло, прекрасне та потворне), що містяться у явищах суспільного життя та природи» (Філософський енциклопедичний словник, 2002, с. 33).

Окреслене поняття інтерпретують по-різному. у роботах вітчизняних і зарубіжних дослідників цінності розглядаються як: ідеал-ідея, зміст якої виражає щось значуще для людини; суть, ті явища природи та суспільства, які $€$ корисними, необхідними людям певного суспільства як дійсності, мети або ідеалів. Як наслідок, цінності можуть бути справжніми та вигаданими, бажаними та ідеальними, це усвідомлений і прийнятий смисл; відображення певної якості ціннісного ставлення людини до світу, яке фіксується у свідомості у вигляді судження про цю якість - оцінки (Бех І. Д., 2003, с. 40).

Таким чином, слід підкреслити, що, незважаючи на безліч підходів до трактування цінностей, учені одностайні в тому, що ця категорія виступає як значущі для особистості предмети та явища навколишньої дійсності, форми прояву певного роду зв'язків між суб'єктом та об'єктом.

Педагогічна наука розглядає цінності з позиції визначення механізмів формування особистості як зміст виховної діяльності та мотивуючий стрижень її поведінки. Вона вивчає практичну діяльність, пов'язану із трансляцією цінностей, насамперед міжпоколінною, з адаптацією індивідів до конкретних умов.

Зокрема, Л. Рубінштейн подає цінність як «значущість людини у світі». Він вважає, що до цінностей належить ідеал-ідея, зміст якої має певну значущість для людини. Також учений наголошує на тому, що «наявність цінностей $є$ вираженням небайдужості людини до світу, яке виникає зі значущості різних сторін, аспектів світу для людини, для її життя» (Рубинштейн С. Л., 2003).

Важливими для нас вважаємо погляди І. Беха, котрий ціннісну систему особистості трактує як складний регулятор людської життєдіяльності, що відображає у своїй структурній організації і змісті особливості об'єктивної дійсності, що охоплює і зовнішній для людини світ, і власне людину в усіх її об’єктивних характеристиках (Бех І. Д., 2003, с. 40).

Як зазначають С. Возняк, В. Кононенко, поняття «цінність» близьке до поняття «значущість». Вони зауважують, що цінністю слід вважати все те, що може підносити особистість, що є для неї значущим і важливим. Власне, йдеться про ту роль, яку предмет чи явище відіграють у життєдіяльності людей з точки зору їхніх потреб, інтересів, цілей.

Цінності у психолого-педагогічних дослідженнях співвідносяться з бажаннями, потребами та ідеалами.

у психологічному словнику зазначено, що особистісним цінностям притаманна висока усвідомленість; вони відображаються у свідомості як ціннісні орієнтації і $€$ важливим чинником регуляції соціальних взаємостосунків людей та поведінки індивіда. Відповідно ціннісні орієнтації визначають: як процес, у результаті якого відбувається 
субординація цінностей, та спосіб диференціації об'єктів за значущістю; система установок щодо дійсності; загальний прийнятий смисл життя; направленість особистості на ті чи інші цінності (В. Тугарінов) (Якісна освіта, 2007).

Отже, під ціннісними орієнтаціями людини слід розуміти певну основу їі духовного світу. Вони є відображенням ставлення людини до світу, до самої себе та здійснюють вплив на активність особистості в соціумі, наповнюючи їі життя смислом. Через ціннісні орієнтації здійснюється засвоєння людиною здобутків духовної культури суспільства. За їх допомогою культурні цінності перетворюються на певні стимули подальшої практичної діяльності та поведінки. Зміст освіти збагачується шляхом накопичення знань про світ, які засвоюються у процесі формування в особи певних ціннісних орієнтацій. Ці знання сприяють кращому розумінню цінностей та традицій інших культур, сприяють формуванню у студентської молоді нової системи позитивних вартостей.

Ми ж спробуємо з'ясувати «сутність освіти як цінності». Освіта - це стимул пізнавальної активності людини, відкриття нового про систему знань, про світ, про особистість. У Національній доктрині розвитку освіти зазначено: «Освіта - основа розвитку особистості, суспільства, нації та держави, запорука майбутнього України. Вона $€$ визначальним чинником політичної, соціально-економічної, культурної та наукової життєдіяльності суспільства. Освіта відтворює і нарощує інтелектуальний, духовний та економічний потенціал суспільства. Освіта є стратегічним ресурсом поліпшення добробуту людей, забезпечення національних інтересів, зміцнення авторитету і конкурентоспроможності держави на міжнародній арені» (Національна доктрина, 2002). Таким чином, підкреслюється провідна роль освіти у житті суспільства та кожної окремої людини.

І водночас освіта $є$ частиною духовної культури особистості, здійснюючи вплив на формування її моральних цінностей, сприяє подальшому розвитку її духовного світу, здібностей та творчого потенціалу людини. Становлення духовного світу молоді має неабиякий вплив на їі життя, суспільство загалом. Тому особливу увагу слід приділити саме формуванню духовно-культурних цінностей освіти як основи для розвитку всебічно та гармонійно розвиненої особистості.

Розуміння духовних цінностей розглядає філософ і педагог М. Бахтін. Він убачає в цінностях і ціннісних орієнтаціях не лише особистісне вираження та потребу, а й аспект вселюдської гуманістичної культури. Учений ставить проблему не контекстуально, а всезагально, пояснюючи, «що означає установлений контекст цінностей?». Дослідник одразу дає відповідь: «сукупність цінностей, цінних не для того чи іншого індивіда і в ту чи іншу епоху, а для всього історичного людства» (Бахтин М.М., 1985, с. 117). Саме тут досить виразно простежується ідея вселюдських базових цінностей для всіх, незалежно від національності, етнічності, віросповідань, політичних систем держав і народів. У різні періоди розвитку людства, як і окремих його складових, духовні цінності набирають специфічних форм та способів, умов їх засвоєння. Звідси можна розглядати духовні цінності як самостійну й багаторівневу галузь вселюдської культури.

Знання, уміння та навички, набутий рівень освіченості поступово втрачають свою цінність, якщо не реалізовуються на практиці. Тому перед сучасними педагогами постає важливе завдання не просто надати студентам певні знання, а навчити їх застосовувати відповідно до вимог сучасного світу. Таку позицію займають і С. Ніколаєнко та В. Тесленко, підкреслюючи, що пріоритетом освіти, яка орієнтується на сучасний ринок праці, є вміння оперувати такими технологіями та знаннями, які будуть задовольняти потреби інформаційного суспільства, підготують молодь до нових ролей у ньому (Якісна освіта, 2007). Не випадково для сучасного студентства надзвичайно важливим завданням $€$ вміння не тільки застосовувати власні знання, а й бути готовим змінюватись та пристосовуватись до нових потреб ринку праці, оперувати й управляти інформацією, активно діяти, швидко приймати рішення. Учені підкреслюють, що досягнення успіху в майбутньому для молоді залежить від уміння вдало використовувати формулу сучасного життя «освіта через усе життя» (Якісна освіта, 2007, с. 219, 227).

Значний інтерес для нас становлять погляди $€$. Бондаревської на сутність освіти. Зокрема, дослідниця зазначає, що «освіта - це духовний обрис людини, який складається у процесі освоєння моральних та духовних цінностей культури» (Бондаревская Е. В., 1999, с. 250-258). І далі підкреслює, що людина визнає значущість освіти, коли пріоритетом навчально-вихованого процесу виступає принцип креативності, який передбачає створення атмосфери співробітництва і співтворчості. Таким чином, творчий підхід до навчання і виховання виступає своєрідним підгрунтям розвитку духовного світу особистості студента.

Аналізуючи сутність та значущість освіти, О. Бадальянц звертає увагу на той факт, що освіта поступово перетворюється в одну з базових суспільно-економічних та інформаційних систем, стає життєво необхідною для кожної людини, чим підкреслюється ї̈ відмінність від традиційних форм. На думку дослідниці, освіта перетворюється у відкриту і тотальну систему: потрібно не лише навчати всіх, але й постійно «переучувати», змінювати кваліфікацію, навчати нової професії». Отже, освіта стає основним інструментом формування гармонійного внутрішнього світу особистості студента, сприяє подальшому розвитку його здібностей та вмінь швидко знаходити вихід із різноманітних конфліктних ситуацій як особистісного (внутрішнього духовного, морального), так і соціального змісту. Вона значно підвищує здатність людини актуалізувати надзвичайно необхідні для життя у сучасному світі параметри особистості, такі, як духовна цілісність, активність та автономність, поступово об'єднуючи їх у певну систему чинників, що здійснюють позитивний вплив на процес самореалізації особистості у реаліях сучасного світу, який постійно змінюється. Тим самим значно мінімізується вірогідність виникнення почуття невпевненості особистості, яке виникає після отримання великої кількості негативної інформації (Філософський енциклопедичний словник, 2002, с. 67-68).

Необхідно звернути увагу на те, що духовно-культурні цінності освіти виявляються в усвідомленні студентською молоддю важливості отримання знань і їх значущості в майбутньому, а також розумінні свого внутрішнього світу, відчутті гармонії із самим собою, оточенням. 
У контексті аналізу проблеми формування духовно-культурних цінностей освіти цікавою постає думка 3. Равкіна про те, що кожна людина повинна знайти своє місце в житті, професії, культурі. Допоможе їй у цьому освіта, яка триває впродовж усього життя і поступово формує в людини розуміння його смислу, значущості цінностей культури, цивілізації, певного народу. Учена зауважує, що деякі люди «...стають повною мірою відповідальними за загальнозначимі цінності, обирають власну світоглядну позицію та загальнокультурну компетентність, але у своєму емоційному, особистісному потенціалі залишаються чужими стосовно до всіх зразків». Вирішити означену проблему можливо за допомогою застосування індивідуального підходу до кожної окремої людини, який передбачає пошук та визначення її емоційного потенціалу, внутрішніх, підсвідомих, навіть ірраціональних потреб (Долженко В. О., 2007).

Цінностями сучасної освіти є культура і людина. Базові складники культури - наука, мистецтво, моральність, релігія, економіка, техніка, технологія - виступають аксіологічною основою освіти, яка доповнюється національними і специфічними цінностями. У центрі цих цінностей стоїть Людина - найвища цінність, яка виступає як правонаступник історичної спадщини і як творчий початок історії. У процесі навчання у закладі вищої освіти студенти набувають навичок з повагою ставитись до особливостей різних культур, у них формується стала ієрархія ціннісних орієнтацій, яка визначає майбутній характер їхньої професійної діяльності та стимулює бажання засвоювати цінності культури.

Таким чином, реалізація у ВНЗ ціннісного підходу молоді до професії, до себе, до оточуючих та спрямованість на розвиток у студентів потреби в усвідомленні цінності життя, результатів власної діяльності, що стає основою досягнення успіху в подальшому житті, сприяє досягненню гармонійного духовно-культурного розвитку особистості в майбутньому.

Цікавою є думка видатного педагога В. Сухомлинського, котрий наголошував: «У наше суспільство прийшла загальна освіченість, до нас має прийти й загальна вихованість - у цій гармонії полягає одна з вирішальних передумов усебічного розвитку всіх. Освіченість, яку ми даємо молодшому поколінню, вимагає високої ідейної, моральної, естетичної, емоційної вихованості, великої людської культури» (Сухомлинський В. О., 1976, с. 53).

Для того, щоб процес виховання був результативним, необхідно сформувати у студентів уявлення про найважливіші цінності життя високоморальної людини, навчити їх бачити відмінність між негативними та позитивними проявами сучасного життя і, найголовніше, допомогти їм знайти відповідь на питання, у чому полягає сутність буття. Слід зазначити, що кожна людина має своє бачення оточуючої дійсності і відповідно до переконань формує власну систему ціннісних орієнтацій (інтересів, потреб, установок, переконань, прагнень, бажань). Саме вони визначають підходи особистості до оточуючих та самої себе.

Так, І. Уварова підкреслює, якщо коли виховання та освіта будуть ґрунтуватися на усвідомленні культурних цінностей, у підростаючого покоління сформується стійкий імунітет до негативних проявів у суспільстві, що дозволить їм розрізняти «прекрасне і потворне, піднесене та низьке як у творах мистецтва, так і в повсякденному житті» (Антоненко Т. Л., 2008). Культура є суспільним явищем, яке виражає досягнутий на даному історичному етапі розвитку суспільства рівень технічного і технологічного прогресу, виробничого досвіду і навичок людей до праці, освіти, науки, мистецтва.

Досить цікавим з точки зору досліджуваної проблеми є визначення понятт «культура», яке дав видатний філософ А. Швейцер: «Культура - сукупність прогресу людини і людства в усіх галузях та напрямах за умови, що цей прогрес служить духовному удосконаленню індивіда як прогресу прогресів (Долженко В. О., 2007). Учений зазначає, що лише справжній прогрес, який веде до вдосконалення особистості, пов'язаний з концептуальною єдністю культури і духовності. На думку А. Швейцера, бездуховна культура - це не стільки культура, скільки антикультура, оскільки призводить до руйнування особистості.

Щодо проблеми співвідношення освіти і культури, слушною вважаємо думку І. Гессена, який не лише зазначив, що між двома поняттями є тісний зв'язок, а також звернув увагу на те, що цілі освіти і культури включають три однакові верстви життя (освіченість, громадянськість, цивілізація), і лише забезпечення їх повної відповідності сприятиме плідному гармонійному розвитку людини. Таким чином, освіта являє собою індивідуальну культуру, «саморозвиток культури»; іншими словами, освіта виконує важливу функцію залучення людини до цінностей культури з метою подальшого розвитку її особистості (Аванесова Г. А., 1998).

Основою будь-якої освіти є залучення людини до культурних цінностей науки, мистецтва, моральності. У наш час гостро постає питання про формування духовно-культурних цінностей освіти. Так, С. Горбенко зазначає, що культура і освіта пов'язані між собою у такий спосіб:

- загальним об'єктом (людина культури і освіти);

- загальнолюдськими цінностями (Культура, Освіта, Людина тощо);

- творчим характером культурно-освітньої діяльності;

- загальними функціями - розвивальною, навчальною, виховною [3, с. 46].

Освіта являє собою частину культури, яка здійснює передачу культурних цінностей суспільства від одного покоління до іншого. Протягом багатьох століть люди створюють та відбирають певні зразки культури, які з часом стають своєрідними нормами поведінки в суспільстві. Із цього приводу Я. Зубова зазначає: «Культура - це, перш за все, сфера цінностей людства. Феномен культури полягає і у відборі певних видів поведінки та певних видів поведінки людей» (Аванесова Г. А., 1998).

Культуру можна зберегти лише через людину. Як слушно зауважує Є. Бондаревська, для цього освіта повинна закласти в неї механізм «культурної ідентифікації» - установлення духовного взаємозв'язку між собою і своїм народом, переживання почуття належності до національної культури, прийняття її цінностей як своїх, вибудовування власного життя з їх урахуванням. 
Таким чином, орієнтація на духовно-культурні цінності - це шлях до формування гармонійної особистості з розвиненим духовним світом, яка намагатиметься реалізувати свій творчий потенціал за законами Істини, Добра та Краси.

\section{ВИСНОВКИ ТА ПЕРСПЕКТИВИ ПОДАЛЬШИХ ДОСЛІДЖЕНЬ}

Отже, формування у студентської молоді духовно-культурних цінностей освіти є неможливим без паралельного духовного розвитку особистості як можливості самореалізації на основі вищих цінностей: моральності, поваги, творчості, взірця для наслідування. Формування у студентів духовно-культурних цінностей освіти стане можливим лише завдяки розвитку їхнього духовного потенціалу, приділенню уваги розкриттю творчих здібностей на основі підвищення зацікавленості у процесі отримання знань.

Перспективу подальшого дослідження вбачаємо в розробці методичних рекомендацій щодо доцільності та ефективності добору методів у навчально-виховному процесі закладу вищої освіти для формування у студентів духовно-культурних цінностей освіти.

\section{СПИСОК ВИКОРИСТАНИХ ДЖЕРЕЛ}

Антоненко, Т. Л. (2008).Ценности и смыслы в контексте психолого-педагогического знания о человеке./ Język wspöłzensnej pedagogiki, 9-17.

Аванесова, Г. А. (1998). Культура духовна. Культурологія XX соліття. Енциклопедія: [в 2 т.], Т.1, 346-347.

Анисимов, С. Ф. (1988). Духовные ценности: производство и потребление. Москва: Мысль.

Бех, І.Д. (2003). Виховання особистості : у 2-х кн. Кн. 2. : Особистісно орієнтований підхід: науково-практичні засади : навч.метод. посібник. Київ: Либідь.

Бахтин, М.М. (1985). К философии поступка. Философия и социология. Москва

Бондаревская, Е. В. (1999). Педагогика: личность в гуманистических теориях и системах воспитания. Ростов.

Бадальянц, О. В. (2005). Образование как социальный фактор повышения безопасности личности в современном мире. Образование как интегративный фактор цивилизационного развития: сб. науч. трудов по материалам межд. науч.практ. конф., Казань, 2005 г. Казань: Издательство «Таглимат», Ч.1, 45-49.

Долженко, В. О. (2007). Виховання духовних цінностей у студентської молоді в полікультурному просторі. (Автореферат дисертації). Східноукраїнський національний університет імені В. Даля. Луганськ.

Національна доктрина розвитку освіти: Указ Президента України №347/2002 від 17 квітня 2002 . Офіційний вісник України, №16, ст. 860.

Постовий, В.Г. (2006). Тенденції і пріоритети виховання дітей в сучасній сім'ї. Київ.

Рубинштейн, С. Л. (2003). Бытие и сознание. Человек и мир. С. Л. Рубинштейн. Санкт-Петербург : Питер.

Сухомлинський,В. О. (1976). Проблеми виховання всебічно розвиненої особистості: Вибрані твори: [в 5 т.]. Київ: Радянська школа, Т.1. 56-78.

Філософський енциклопедичний словник. (2002). Київ : Абрис.

Якісна освіта - запорука самореалізації особистості .(2007). Київ: Пед. преса.

\section{REFERENCES}

Antonenko T. L. (2008). Tsennosty y smysly v kontekste psykholoho-pedahohycheskoho znanyia o cheloveke. Język wspőłzensnej pedagogik, 9-17.

Avanesova, H. A. (1998). Kultura dukhovna. Kulturolohiia XX stolittia. Entsyklopediia: [v 2 vol.], Vol. 1, 346-347.

Anysymov, S. F. (1988). Dukhovnye tsennosty: proyzvodstvo y potreblenye. Moscow: Mysl.

Bekh, I.D. (2003). Vykhovannia osobystosti (Parenting): u 2-kh . Kn. 2. : Osobystisno oriientovanyi pidkhid: naukovo-praktychni zasady : navch.-metod. Posibnyk. Kyiv : Lybid.

Bakhtyn, M.M. (1985). K fylosofyy postupka. Fylosofyia y sotsyolohyia. Moscow.

Bondarevskaia, E. V. (1999). Pedahohyka: lychnost v humanystycheskykh teoryiakh y systemakh vospytanyia. Rostov-na-Donu.

Badaliants, O. V. ((2005). Obrazovanye kak sotsyalnyi faktor povyshenyia bezopasnosty lychnosty v sovremennom myre. Obrazovanye kak yntehratyvnyi faktor tsyvylyzatsyonnoho razvytyia: sb. nauch. trudov po materyalam mezhd. nauch.-prakt. konf., Kazan, 2005. Kazan: Tahlymat, Vol.1, 45-49.

Dolzhenko,V. O. (2007). Vykhovannia dukhovnykh tsinnostei u studentskoi molodi v polikulturnomu prostori. (Extended Abstract of Candidate's thesis). Skhidnoukrainskyi natsionalnyi universytet imeni V. Dalia. Luhansk.

Natsionalnu doktrynu rozvytku osvity (2002). Ukaz Prezydenta Ukrainy № 347/2002 vid 17 kvitnia 2002. Ofitsiinyi visnyk Ukrainy, No 16 , St. 860

Postovyi ,V.H. (2006). Tendentsii i priorytety vykhovannia ditei v suchasnii simi. Kyiv.

Rubynshtein, S. L. (2003). Bytye y soznanye. Chelovek y myr. S. L. Rubynshtein. St. Petersburg: Pyter.

Sukhomlynskyi ,V. O. (1976). Problemy vykhovannia vsebichno rozvynenoi osobystosti. Vybrani tvory: [v 5 vol.]. Kyiv: Radianska shkola, Vol, $1,56-78$

Filosofskyi entsyklopedychnyi slovnyk. (2002). Kyiv : Abrys.

Yakisna osvita - zaporuka samorealizatsii osobystosti. (2007). Kyiv: Ped. presa.

Статтю подано до редколегії 17.01.2019 р.

Рекомендовано до друку $\quad$ 02.02.2019 p. 